\title{
The effects of adding inactive yeast culture (Saccharomyces Cerevisiae) to rations prepared with different quality roughages on fattening performance, nutrient digestibility, some rumen parameters and carcass yield in lambs
}

\author{
Duygu Budak ${ }^{1 *}$, Aydan Yılmaz²@) \\ ${ }^{1}$ Aksaray University, Faculty of Veterinary Medicine, Department of Zootechnical and Animal Nutrition, Aksaray, Turkey. \\ ${ }^{2}$ Ankara University, Faculty of Agriculture, Department of Feeds and Animal Nutrition, Ankara, Turkey.
}

\section{Article History}

Received: 16 June 2020

Accepted: 18 November 2020

First Online: 25 December 2020

\section{Corresponding Author}

Tel.: +903822882862

E-mail: budakduygu@aksaray.edu.tr

\section{Keywords}

Roughage

Inactivated yeast

Digestibility

Rumen parameters

Temperature

Lamb

\begin{abstract}
This study was performed with the participation of $26.22 \pm 1.07 \mathrm{~kg}$ average weighted 36 singleton lambs. 6 Groups were formed; 3 with IYM ( $7 \mathrm{~g} /$ day) and 3 without IYM. Lambs were kept in individual divisions and given $150 \mathrm{~g} /$ day roughage (alfa alfa hay $(\mathrm{AH})$, meadow hay (MH), wheat straw (WS), concentrated feed and water ad libitum. Treatment lasted 70 days in total; temperature and humidity were recorded daily. Fattening performance, carcass parameters and ruminal $\mathrm{pH}$ levels were not affected by the treatment $(P>0.05)$. Additive increased the weight of the hearts which were fed with $\mathrm{AH}(\mathrm{P}<0.05)$. Effects of roughage and additive interactions on the acetic, propionic and volatile fatty acids was found as significant $(\mathrm{P}<0.01)$. IYM, increased the rates of acetic acid/propionic acid feeding with $\mathrm{AH}$ and $\mathrm{MH}(\mathrm{P}<0.05)$. Ammonia concentration and digestibility of crude cellulose and hemicellulose was affected by the type of roughage $(P<0.05)$. Digestibility of acid detergent fibre $(P<0.01)$ and cellulose $(P<0.001)$ was increased with additives. There is no difference among the groups in terms of water consumption $(P>0.05)$. It's concluded that, temperature and humidity is an efficient environmental factor on the fattening performance and IYM have positive effects on some cell-wall components digestibility and rumen parameters.
\end{abstract}

\section{Introduction}

Roughage is a stimulant factor in all processes of the digestion system of developing ruminant from the development of microflora to obtaining efficiency. However, as this stimulant is not sufficient it is emphasized that age and genus of the animal and usage of expedient feed additives together can create important effects. IYM are distinct among feed additives for their natural and biotechnological feature. Inactive yeast are probiotic metabolites as a good vitamin and mineral source produced mostly as high biologic value proteins after the fermentation of probiotic live yeast cells in an anaerobe culture medium with carbohydrate (Inge et al. 2009, Eze- ma 2013, Anonymous 2014a,b). By means of improving the adaptation ability of farm animals to poor conditions and increasing their resistance against diseases and their genetic potentials they serve as potential alternatives for antibiotics. (Abd-El Ghani 2004, Moharrery and Asadi 2009). In recent years it has drawn attention for its decreasing effects on metabolic disease risks (Vyas et al. 2014).

It is reported that by using IYM in ruminant rations more benefit can be provided than roughage especially of low-quality (Tripathi and Karim 2011, Zain et al. 2011). It is emphasized those effects result from the modification of rumen fermentation and thus they depend 
on the composition of ration used (Kocaoglu and Kara 2010, Anonymous 2014a, b). Therefore, enhancement is achieved in the rate of animal's utilization from feed (Karademir and Karademir 2003, Turkmen et al. 2011) and it is observed that digestibility of some nutrients are increased (Haddad and Goussous 2005, Ghoneem and Mahmoud 2014). Effects of IYM on rumen parameters were associated with the quality of roughage aside from ration composition primarily (Opsi et al. 2012, Jurkovich et al. 2014). Also, its effects are expected on preserving the $\mathrm{pH}$ level of rumen by consuming the oxygen produced by aerobic pathogen (Ghoneem and Mahmoud 2014) and transforming ammonia nitrogen into microbial protein by increasing the density of bacteria in rumen (Patra 2012).

On the other hand, it is emphasized that ambient temperature and humidity is an important environmental factor where ruminants can easily maintain their body temperature during growing and development periods (Niyas et al. 2015) and the effects of ration composition against variable environment factors are a question of interest.

Through this study it is aimed to determine the effects of supplementation of inactivated yeast metabolites (IYM) (Saccharomyces cerevisiae) to rations containing alfalfa hay (AH) meadow hay ( $\mathrm{MH}$ ) and wheat straw (WS) for Anatolian Merino Sheep in terms of fattening performance, digestibility of nutrients, some rumen parameters and carcass yield.

\section{Materials and Methods}

This study was carried out with the decision of the local ethics committee of animal experiments in ankara university with the code 2014-22-151.

\section{Trial Plan and Feeds}

Animal materials; comprised of $26.22 \pm 1.07 \mathrm{~kg}$ average live weight and weaned at age of 2,5 months 36 singleton male Anatolia Merino lambs. In the study which was performed between September and November (out of weaning season) lambs were weighed at the beginning of trial and grouped according to their live weights homogeneously and randomly. For each roughage used in rations 6 trial groups were formed; 3 with IYM and 3 without IYM. During the study performed on factorial experiment design basis ( 3 roughages $x 2$ levels) lambs were fed in individual partitions for 70 days; 10 days being the adaptation period to the feed and the following 60 days for main fattening period. Lambs were given 150 gr 3-5 cm size chopped roughage (by considering the feeding of dry matter equal to roughage) (NRC 2007) and IYM was added to the roughage for $7 \mathrm{~g} /$ day of the groups taking additive feed (Anonymous 2015). After the mixture of yeast metabolite and roughage was consumed by the animals, concentrate feed and clean water were provided ad-libitum. Lamb fattening feed (LFF) was supplied from a feed factory. Inactive Yeast Culture was used as inactivated yeast metabolite (IYM) (Anonymous 2015).

A.O.A.C. 1984 was used as the method of determining the values of dry matter (DM) crude protein $(\mathrm{CP})$, crude cellulose (CC), ether extract (EE) and crude ash (CA); Van Soest, 1994 procedure was followed for determining the amounts neutral detergent fibre (NDF), acid detergent fibre (ADF) and acid detergent lignin (ADL); and for IYM Anonymous 2015 values were used. Metabolic energy (ME) (Anonymous 2016), organic matter $(\mathrm{OM}=\mathrm{DM}-\mathrm{CA})$, non-nitrogen extract $(\mathrm{NNE}=\mathrm{DM}$ $(C P+C A+E E+C C))$, hemicellulose (HCL=NDF-ADF), cellulose ( $C L=A D F-A D L)$ and lignin ( $L=A D L$-insoluble ash) values were derived from the analysis results on feed materials through calculation (Table 1).

Table 1. Chemical composition of feed and inactivated yeast metabolites used in the study

\begin{tabular}{lccccc}
\hline & AH & MH & WS & LFF & IYM \\
\hline ME,Mcal/kgDM & 1.38 & 1.76 & 1.37 & 2.73 & - \\
DM, \% & 93.25 & 93.35 & 92.90 & 90.44 & - \\
\hline OM, \% & 85.09 & 81.39 & 83.5 & 82.22 & - \\
\hline $\mathrm{CP}, \%$ & 11.55 & 9.16 & 4.20 & 17.41 & 15.0 \\
\hline $\mathrm{CC}, \%$ & 38.98 & 27.56 & 37.37 & 9.73 & - \\
$\mathrm{EE}, \%$ & 0.99 & 1.60 & 1.09 & 2.85 & 3.0 \\
$\mathrm{CA}, \%$ & 8.16 & 11.96 & 9.40 & 8.22 & 6.0 \\
$\mathrm{NNE}, \%$ & 33.57 & 43.07 & 40.84 & 52.23 & - \\
\hline $\mathrm{NDF}, \%$ & 62.73 & 60.70 & 75.02 & 41.43 & - \\
$\mathrm{ADF}, \%$ & 34.00 & 44.52 & 53.69 & 12.61 & - \\
$\mathrm{ADL}, \%$ & 9.76 & 10.04 & 12.36 & 6.38 & - \\
$\mathrm{HCL}, \%$ & 28.74 & 16.17 & 21.33 & 28.82 & - \\
$\mathrm{CL}, \%$ & 24.24 & 34.48 & 41.33 & 6.23 & 8.0 \\
\hline $\mathrm{L}, \%$ & 8.46 & 7.78 & 10.09 & 5.14 & - \\
\hline
\end{tabular}

\section{Temperature and Humidity}

During the trial outdoor and in-barn temperatures $\left({ }^{\circ} \mathrm{C}\right)$ and percentage of in-barn humidity (\%) were measured every day at exact times (07:00, 14:00 and 21:00), thus the maximum and minimum temperatures were determined together with the in-barn humidity values. In consideration of those values and differences of maximum-minimum temperatures and humidity; daily average temperature and humidity values were calculated. Daily average temperatures were calculated based on the formula of Dağsöz and Bayraktar 1999 and humidity values were derived from the average of three measurements. 
Daily average temperature $\left({ }^{\circ} \mathrm{C}\right)=(\mathrm{t} 7+\mathrm{t} 14+2 \times \mathrm{t} 21)$ /4 t (hour): temperature measured at 7, 14 and 21

\section{Parameters of Fattening Performance}

Live weight (LW) values were measured on individual basis at the beginning of the feeding period and were continued to be recorded every two weeks until the end of the trial. Animals were weighted before feeding in the mornings at the same time (08:00). 12 hours before the weighing lambs were left hungry. Live weight gain (LWG) were measured daily and separately in all trial periods during the study. Individual feed consumption of lambs was calculated daily by taking the difference between the weight of morning feed and the amount left after feeding. Daily live weight gain was calculated by using these recorded data. Based on the data collected from this procedure, feed convertion ratio (FCR) was calculated.

\section{Digestibility Parameters and Water Consumption}

Manure collecting method was used for the determination of in vivo digestibility for $\mathrm{DM}, \mathrm{OM}, \mathrm{CP}, \mathrm{CC}, \mathrm{EE}$, CA, NNE, NDF, ADF, HCL and CL rations (Akyildiz 1984). For this purpose, during the last 10 days of fattening every morning before feeding lamb's stool collected from the zippered manure bags which were attached to them. $10 \%$ of collected stool was weighted wet and the remaining part was weighted after drying in drier chamber at $60^{\circ} \mathrm{C}$ for 72 hours and then grinded as to pass a $2 \mathrm{~mm}$ sifter. Samples were taken for ten days from each lamb and 360 samples were obtained in total. After those 10day samples were combined for each lamb 36 samples were analysed. All the manure samples ready for analysis were studied with (A.O.A.C. 1984) method for DM, CP, CC, EE and CA analysis and (Van Soest 1994) for NDF, ADF and $A D L$ analysis. Based on the results of these analysis $\mathrm{OM}(\mathrm{OM}=\mathrm{DM}-\mathrm{CA}), \mathrm{NNE}(\mathrm{NNE}=\mathrm{DM}-(\mathrm{CP}+\mathrm{CA}+\mathrm{EE}+\mathrm{CC})), \mathrm{HCL}$ ( $H C L=N D F-A D F)$ and $C L$ (CL=ADF-ADL) values in manure were calculated. Finally based on the results of analysis such as consumed feed ration and nutrient analysis in manure, in vivo nutrients digestibility (\%) of rations were found. Also, during last 6 day of the collecting manure period individual daily water consumptions of lambs were determined.

\section{Rumen Parameters}

Following the process of collecting the residual feed and manure at the last day of fattening, last live weighting was measured and rumen liquid was extracted by rumen catheter from all lambs. During this period mangers were left empty and animals were allowed to drink water. Measurements of $\mathrm{pH}$ in rumen liquid was performed by automatic $\mathrm{pH}$ meter (ADWA AD12) and rumen liquid was collected in 3 different sample bottles which were taken from each animal. Those sample bottles were kept in dry ice cabinet at $-20^{\circ} \mathrm{C}$ until analyses.

Gas chromatography was used for the determination of volatile fatty acids (acetic acid, propionic acid, butyric acid, iso butyric acid, valeric acid, isovaleric acid) (Playne 1985, Zdunczyk et al. 2013). Samples were first melt at $4^{\circ} \mathrm{C}$ and then centrifuged at $4000 \mathrm{rpm}$ for $15 \mathrm{~min}$ utes. After that, $1 \mathrm{ml}$ of supernatant was taken into 1.5 $\mathrm{ml}$ volume capped tube and then $0.2 \mathrm{ml} \% 25$ metaphosphoric acid solution was added. Tubes were kept on ice for 30 minutes in order to provide protein precipitation and then centrifuged at $11000 \mathrm{rpm}$ at $+4^{\circ} \mathrm{C}$ again. Carrier gas was Helium ( $\mathrm{He}$ ) and column temperature was programmed to increase from $120^{\circ} \mathrm{C}$ up to $160^{\circ} \mathrm{C}$ gradually during the analysis. Before the analysis, standards were prepared with Volatile Free Acid Mix. 46975-U (10 $\mathrm{mmol} / \mathrm{L}$ ) and 1 microlitre rumen liquid taken by means of 10 microlitre injector were injected into gas chromatography device (Shimadzu GC-2010). Temperature of injection block was set to $230^{\circ} \mathrm{C}$, FID (Flame ionization detector) temperature of detector was set to $250^{\circ} \mathrm{C}$, dry air and hydrogen gas pressure was set to $0.5 \mathrm{~kg} / \mathrm{cm}^{3}$ and analysis was performed by using capillary column.

For ammonia $\left(\mathrm{NH}_{3}\right)$ analysis, samples were thawed at $4^{\circ} \mathrm{C}$ then centrifuged at $14000 \mathrm{rpm}$ at $4^{\circ}$ for $15 \mathrm{~min}$ utes. After centrifugal process concentration of $\mathrm{NH}_{3}-\mathrm{N}$ was marked with indophenol blue method by using UV/ Visible spectrophotometer device (Chaney and Marbaeh 1962). In this method ammonia and phenol sodium were oxidised with sodium nitroprusside and a blue colour complex was created. The intensity of blue colour is directly proportional to the concentration of $\mathrm{NH}_{3}-\mathrm{N}$ in the sample.

\section{Carcass Parameters}

At the end fattening period, all lambs were slaughtered and weighed for their slaughter weights $(\mathrm{kg})$, after the extraction of internal organs they were weighed for hot carcass weights $(\mathrm{kg})$ and then the hot carcasses were kept at $+4^{\circ} \mathrm{C}$ for 24 hours in order to note the cold carcass weight $(\mathrm{kg})$ values. Extracted organs were weighed and marked separately in grams. Based on values of slaughter and hot and cold carcass weights hot and cold carcass efficiency (\%) values were calculated using the below formula (Rentfrow 2010).

Hot carcass efficiency (\%): (Hot carcass weight / Slaughter weight) $\times 100$

Cold carcass efficiency (\%): (Cold carcass weight / Slaughter weight) $\times 100$ 


\section{Statistical Analysis}

Data were analysed using Variant Analysis Technique based on factorial design random testing. (Duzgunes et al. 1987). Different groups were determined by using Duncan Multiple Comparison Test (Duncan 1955). Variants analysis and Duncan Tests SPSS 15 were carried out by running statistical package programmes (Anonymous 2006).

\section{Results}

\section{Temperature and Humidity}

Outdoor and indoor temperature and humidity values during different fattening periods of closed type sheep barn where fattening was carried out and throughout the fattening periods were given in Table 2. As shown in the table from the early period of fattening minimum and maximum temperatures of inside and accordingly outside of sheep barn were quite low in period transitions $(P<0.001)$, barn interior temperature difference between day and night was minimum in the early period and reached maximum in the late period $(P<0.05)$. Also, significant variations were determined at maximum and minimum humidity rates of sheep barn during the fattening periods.

\section{Fattening Performance}

At the beginning of the research, performance parameters of lambs in 2-week periods and throughout fattening are given in Table 3. Live weight (LW), feed consumption (FC), live weight gain (LWG) and feed convertion ratio ( $F C R$ ) were not affected by the treatment $(P>0.05)$, while feedxadditive interaction was found meaningful in terms of LWG $(P=0.001)$ between groups in the $6^{\text {th }}$ week of fattening period, lambs fed with $\mathrm{MH}$ exhibited more LWG than lambs fed with WS

Table 2. Average values of in and out ambient temperature $\left({ }^{\circ} \mathrm{C}\right)$ and humidity in during and different fattening periods $(\%)$

\begin{tabular}{|c|c|c|c|c|c|c|c|}
\hline \multirow[t]{2}{*}{ PROPERTIES } & \multicolumn{5}{|c|}{ PERIODS } & \multirow{2}{*}{\multicolumn{2}{|c|}{$\mathbf{P}$}} \\
\hline & 0-2 week & 2-4 week & 4-6 week & 6-8 week & 0-8 week & & \\
\hline \multicolumn{8}{|c|}{ Out Ambient Temperature } \\
\hline Minimum & $14.5 \mathrm{Aa}$ & $12.8 \mathrm{Aab}$ & $11.1 \mathrm{Bb}$ & $3.7 C$ & 10.5 & $*$ & $* *$ \\
\hline Maximum & $23.9 \mathrm{~A}$ & $21.8 \mathrm{~A}$ & $16.5 B$ & $9.9 \mathrm{C}$ & 18.0 & $*$ & $* *$ \\
\hline Average & $20.5 \mathrm{Aa}$ & $18.5 \mathrm{Aa}$ & $14.4 \mathrm{Bb}$ & $7.2 \mathrm{C}$ & 15.2 & $*$ & $* *$ \\
\hline Min.-Max. Difference & $9.4 a$ & $9.0 \mathrm{ac}$ & $5.4 \mathrm{bd}$ & $6.2 \mathrm{~cd}$ & 7.5 & $*$ & $* *$ \\
\hline \multicolumn{8}{|c|}{ In Ambient Temperature } \\
\hline Minimum & $21.6 \mathrm{~A}$ & $17.9 \mathrm{~B}$ & $14.3 \mathrm{C}$ & $7.0 \mathrm{D}$ & 15.2 & $*$ & $* *$ \\
\hline Maximum & 24.0Aa & 21.9Aa & $18.1 \mathrm{Bb}$ & $12.3 \mathrm{C}$ & 19.1 & $*$ & $* *$ \\
\hline Average & 23.2Aa & $20.2 \mathrm{Bb}$ & $16.8 \mathrm{C}$ & $10.3 \mathrm{D}$ & 17.6 & $*$ & $* *$ \\
\hline Min.-Max. Difference & $2.5 a$ & 4.0 & 3.8 & $5.3 b$ & 3.9 & $*$ & $* *$ \\
\hline \multicolumn{8}{|l|}{ In Ambient Humidity } \\
\hline Minimum & 63.7Aa & $74.3 \mathrm{bd}$ & $75.4 \mathrm{Bb}$ & $67.2 \mathrm{ad}$ & 70.2 & $* *$ & $* *$ \\
\hline Maximum & $71.3 \mathrm{~A}$ & 81.7B & $80.5 \mathrm{Ba}$ & $72.3 \mathrm{Ab}$ & 76.5 & $* *$ & $* *$ \\
\hline Average & $67.2 \mathrm{Aa}$ & $77.6 \mathrm{Bb}$ & $77.0 \mathrm{~b}$ & $69.6 a$ & 72.8 & $*$ & $* *$ \\
\hline Min.-Max. Difference & 7.6 & 7.3 & 5.1 & 5.1 & 6.3 & & \\
\hline
\end{tabular}

* Difference among the averages shown with different lower case on the same line are significant $(P<0.05)$.

** Difference among the averages shown with different upper case on the same line are significant $(P \leq 0.001)$

\section{Digestibility of Nutrients and Water Consumption}

Averages of nutrient digestibility of rations (DM, $\mathrm{OM}, \mathrm{CP}, \mathrm{CC}, \mathrm{EE}, \mathrm{CA}, \mathrm{NNE}, \mathrm{NDF}, \mathrm{ADF}, \mathrm{HCL}$ and $\mathrm{CL}$ ) are given in Table 4. Accordingly, differences between roughage sources in terms of digestibility of ration CC were found significant $(P<0.05)$, roughage containing additive had no effect on the digestibility of ration CC ( $P>0.05)$. It is observed that ration CC was digested better by lambs consuming ration with $\mathrm{MH}$ than lambs consuming ration with WS $(P<0.05)$ and highest digestion levels were achieved with lambs fed with WS+IYM. Additives increased the digestibility of ADF in all groups consuming roughage $(P<0.01)$, while ration cellulose digestibility increased in the group consuming feed with additive in WS $(P<0.001)$. While the differences between roughage sources in terms of $\mathrm{HCL}$ digestibility of ration were found significant $(P<0.05)$, additive in roughage had no effect on the digestibility of $\mathrm{HCL}$ ration $(P>0.05)$. Lambs fed with ration containing $\mathrm{AH}$ had higher rate of $\mathrm{HCL}$ digestibility of ration than the group consuming $\mathrm{MH}(\mathrm{P}<0.05)$. By the last day of fattening no difference was not noted in terms of water consumption among the groups ( $P>0.05$ ) (Table 4). 
Table 3. Averages of performance parameters of Anatolian Merino lambs

\begin{tabular}{|c|c|c|c|c|c|c|c|c|c|}
\hline \multirow[b]{2}{*}{ Properties } & \multicolumn{6}{|c|}{ TRIAL GROUPS } & \multicolumn{3}{|c|}{ P VALUES } \\
\hline & $\mathbf{A H}$ & $\mathrm{MH}$ & WS & $A H+I Y M$ & MH+IYM & WS+IYM & feed & additive & $\begin{array}{c}\text { Feed } \mathbf{x} \\
\text { additive }\end{array}$ \\
\hline \multicolumn{10}{|l|}{ LW, kg } \\
\hline Beginnig & 26.150 & 26.016 & 26.033 & 26.685 & 26.175 & 26.300 & 0.923 & 0.712 & 0.840 \\
\hline 0-2 week & 30.750 & 30.816 & 31.083 & 32.085 & 30.900 & 31.633 & 0.640 & 0.401 & 0.855 \\
\hline 2-4 week & 34.850 & 34.183 & 34.966 & 35.500 & 34.200 & 35.183 & 0.715 & 0.717 & 0.691 \\
\hline 4-6 week & 38.475 & 38.733 & 38.166 & 38.728 & 37.800 & 39.183 & 0.981 & 0.293 & 0.801 \\
\hline 6-8 week & 41.550 & 41.866 & 41.316 & 41.785 & 40.475 & 42.450 & 0.935 & 0.094 & 0.400 \\
\hline \multicolumn{10}{|l|}{ LWG, kg } \\
\hline 0-2 week & 4.600 & 4.950 & 4.800 & 5.371 & 4.925 & 5.334 & 0.613 & 0.161 & 0.951 \\
\hline 2-4 week & 4.100 & 3.267 & 3.367 & 3.500 & 4.075 & 3.550 & 0.436 & 0.115 & 0.262 \\
\hline 4-6 week & $3.625 a b$ & $3.850 \mathrm{ab}$ & $4.550 \mathrm{~b}$ & $3.257 a b$ & $2.575 a$ & $4.000 \mathrm{~b}$ & 0.190 & 0.672 & $0.001^{*}$ \\
\hline 6-8 week & 3.075 & 3.134 & 3.134 & 2.700 & 3.325 & 3.267 & 0.651 & 0.675 & 0.814 \\
\hline 0-8 week & 15.400 & 15.200 & 15.850 & 14.828 & 14.900 & 16.150 & 0.923 & 0.984 & 0.151 \\
\hline \multicolumn{10}{|l|}{$\mathrm{FC}, \mathrm{kg} /$ day } \\
\hline 0-2 week & 1030.28 & 994.98 & 1057.23 & 1059.66 & 1011.89 & 1077.20 & 0.305 & 0.663 & 0.286 \\
\hline 2-4 week & 1482.97 & 1426.54 & 1427.13 & 1416.63 & 1454.94 & 1493.83 & 0.154 & 0.681 & 0.270 \\
\hline 4-6 week & 1897.62 & 1828.47 & 1875.02 & 1867.15 & 1881.60 & 1981.14 & 0.322 & 0.847 & 0.240 \\
\hline 6-8 week & 1939.19 & 1785.58 & 1819.90 & 1819.54 & 1844.26 & 1956.50 & 0.316 & 0.753 & 0.076 \\
\hline 0-8 week & 1587.52 & 1546.66 & 1508.90 & 1554.48 & 1521.38 & 1627.17 & 0.279 & 0.134 & 0.071 \\
\hline LWG, g/day & 275 & 271 & 283 & 265 & 266 & 289 & 0.923 & 0.973 & 0.151 \\
\hline FCR (0-8 week) & 5.775 & 5.724 & 5.356 & 5.931 & 5.753 & 5.646 & 0.850 & 0.382 & 0.135 \\
\hline
\end{tabular}

* Difference between the averages shown with different lower case on the same line are significant $(P \leq 0.001)$.

Table 4. Average values of nutrients digestibility of rations and water consumption of lambs

\begin{tabular}{|c|c|c|c|c|c|c|c|c|c|}
\hline \multirow[t]{2}{*}{ PROPERTIES } & \multicolumn{6}{|c|}{ TRIAL GROUPS } & \multicolumn{3}{|c|}{ P VALUES } \\
\hline & $\mathrm{AH}$ & $A H+I Y M$ & MH & MH+IYM & WS & WS+IYM & feed & additive & $\begin{array}{c}\text { Feed } \mathbf{x} \\
\text { additive }\end{array}$ \\
\hline \multicolumn{10}{|l|}{ Digestibility, \% } \\
\hline DM & 75.35 & 74.08 & 73.17 & 73.73 & 74.08 & 74.95 & 0.238 & 0.933 & 0.403 \\
\hline OM & 77.23 & 75.85 & 75.75 & 75.73 & 75.72 & 75.72 & 0.497 & 0.614 & 0.464 \\
\hline $\mathrm{CP}$ & 81.01 & 78.12 & 79.03 & 78.58 & 78.51 & 77.67 & 0.286 & 0.060 & 0.338 \\
\hline $\mathrm{CC}$ & $52.23 \mathrm{ab}$ & $48.58 a b$ & $45.92 b$ & $48.83 b$ & $52.68 a$ & $53.41 a$ & $0.017^{*}$ & 0.998 & 0.222 \\
\hline $\mathrm{EE}$ & 89.64 & 89.70 & 86.89 & 89.23 & 87.31 & 88.17 & 0.308 & 0.305 & 0.643 \\
\hline CA & 56.79 & 52.41 & 47.55 & 54.79 & 53.94 & 51.41 & 0.562 & 0.967 & 0.148 \\
\hline NNE & 81.10 & 79.88 & 80.61 & 80.13 & 80.16 & 80.98 & 0.965 & 0.638 & 0.444 \\
\hline NDF & 64.53 & 61.84 & 58.81 & 61.64 & 61.38 & 64.13 & 0.141 & 0.476 & 0.184 \\
\hline$A D F$ & $40.55 a$ & $45.34 b$ & $43.03 a$ & $48.97 b$ & $42.27 a$ & $51.17 b$ & 0.263 & $0.002 * *$ & 0.682 \\
\hline $\mathrm{CL}$ & $70.87 a$ & 78.54ab & 74.07ab & 79.58ab & $70.81 a$ & $81.56 b$ & 0.583 & $0.000 * * *$ & 0.449 \\
\hline $\mathrm{HCL}$ & $73.75 b$ & 69.87ab & $68.80 a$ & 68.19a & $69.53 a b$ & 69.97ab & $0.013 *$ & 0.131 & 0.144 \\
\hline \multicolumn{10}{|c|}{ Water consumption, It } \\
\hline 5. Day & 4.3755 & 4.167 & 4.134 & 4.188 & 4.250 & 3.817 & 0.719 & 0.395 & 0.670 \\
\hline 6. Day & 4.87 & 4.284 & 4.000 & 4.828 & 4.125 & 4.434 & 0.673 & 0.494 & 0.094 \\
\hline 7. Day & 4.375 & 4.084 & 4.517 & 4.300 & 3.800 & 3.367 & 0.273 & 0.950 & 0.195 \\
\hline 8. Day & 4.000 & 3.550 & 3.834 & 3.614 & 3.725 & 3.700 & 0.146 & 0.692 & 0.133 \\
\hline 9. Day & $4.450 \mathrm{a}$ & $4.217 a$ & $3.617 b$ & $4.386 a$ & $4.475 a$ & $3.534 b$ & 0.487 & 0.595 & $0.026 * *$ \\
\hline 10. Day & 3.375 & 3.300 & 3.034 & 3.286 & 3.200 & 3.250 & 0.326 & 0.444 & 0.371 \\
\hline
\end{tabular}

Difference among the averages shown with different letters on the same line are significant $*(P<0.05) * *(P<0.01) * * *(P<0.001)$. 
Table 5. Average values of rumen parameters obtained from trial groups ( $\mathrm{Mmol} / \mathrm{lt}$ )

\begin{tabular}{|c|c|c|c|c|c|c|c|c|c|}
\hline \multirow[t]{2}{*}{ PROPERTIES } & \multicolumn{6}{|c|}{ TRIAL GROUPS } & \multicolumn{3}{|c|}{ P VALUES } \\
\hline & $\mathrm{AH}$ & $A H+I Y M$ & MH & MH+IYM & WS & WS+IYM & feed & additive & $\begin{array}{c}\text { Feed } \mathbf{x} \\
\text { additive }\end{array}$ \\
\hline Acetic acid & $27.41 a$ & $28.73 a b$ & $33.04 a c$ & $28.10 b$ & $26.96 a$ & $33.90 c$ & 0.320 & 0.457 & $0.008 * *$ \\
\hline Propionic acid & 13.17ab & $9.96 a$ & $15.05 b$ & $9.93 a$ & 11.51ab & $15.15 b$ & 0.353 & 0.108 & $0.002 * *$ \\
\hline Butyric acid & 8.10 & 9.43 & 10.23 & 9.86 & 7.70 & 9.40 & 0.333 & 0.343 & 0.598 \\
\hline İsobutyric acid & 1.11 & 1.22 & 1.19 & 1.18 & 1.15 & 1.23 & 0.954 & 0.385 & 0.699 \\
\hline Valeric acid & 1.38 & 1.41 & 1.47 & 1.43 & 1.34 & 1.77 & 0.573 & 0.249 & 0.256 \\
\hline İsovaleric acid & 1.23 & 1.33 & 1.33 & 1.27 & 1.25 & 1.39 & 0.961 & 0.499 & 0.672 \\
\hline TVFA & $52.41 a$ & $52.09 a$ & $62.31 b$ & $51.78 a$ & $49.91 a$ & $62.84 b$ & 0.331 & 0.804 & $0.006 * *$ \\
\hline$A / P$ & $2.11 a$ & $2.92 b$ & $2.26 a$ & $2.93 b$ & $2.37 a$ & $2.31 \mathrm{a}$ & 0.515 & $0.015^{*}$ & 0.145 \\
\hline Ammonia & $1.78 \mathrm{a}$ & $3.45 a$ & $4.09 b$ & $4.11 b$ & $2.87 a$ & $2.36 a$ & $0.030^{*}$ & 0.455 & 0.242 \\
\hline $\mathrm{pH}$ & 7.12 & 7.17 & 6.98 & 7.08 & 7.05 & 6.97 & 0.607 & 0.861 & 0.793 \\
\hline
\end{tabular}

Differences among the averages shown with different letters on the same line are significant. ${ }^{*}(\mathrm{P}<0.05), * *(P<0.01)$.

\section{Rumen Parameters}

Feed $\mathrm{x}$ additive interaction was found significant among the groups in terms of acetic acid and propionic acid $(P<0.01)$. Additive agent decreased the rumen acetic and propionic acid molar concentration in the group consuming $\mathrm{MH}$, whereas it increased the acetic acid molar concentration in the group consuming WS $(P<0.05)$ (Table 5). Effects of roughage type and additive agent on the concentrations of butyric acid, isobutyric acid, valeric acid and isovaleric acid were found similar ( $P>0.05)$. Feed $x$ additive interaction between groups was found significant in terms of Total Volatile Fatty Acid (TVFA) $(P<0.01)$. While the IYM did not affect the amount of rumen TVFA in the groups consuming $\mathrm{AH}(\mathrm{P}>0.05)$ it caused decrease in the groups consuming $\mathrm{MH}(\mathrm{P}<0.01)$ and caused increase in the groups consuming WS $(P<0.01)$.
For lambs fed with rations containing $\mathrm{MH}$ and WS+IYM, rumen TVFA molar concentration was found similar and significantly higher than the other groups $(P<0.01)$. Additive agent in $\mathrm{AH}$ and $\mathrm{MH}$ increased the rate of rumen acetic acid/propionic acid $(A / P)(P<0.05)$. In the group of lambs feeding with $\mathrm{MH}$ ratio of rumen to ammonia was higher than the other groups $(P<0.05)$ but no difference was seen among groups in terms of ruminal $\mathrm{pH}$ values ( $P>0.05)$.

\section{Carcass Parameters and Internal Organ Weights}

Carcass parameters (hot and cold carcass weights, their yields and slaughter weights) and weights of some internal organs (spleen, liver and lung) were not affected from roughage or roughage containing IYM ( $P>0.05)$, but weight of heart was increased with additive agent in $\mathrm{AH}$ $(\mathrm{P}<0.05)$ (Table 6).

Table 6. Averages of carcass parameters and weights of some internal organs according to the trial on groups.

\begin{tabular}{|c|c|c|c|c|c|c|c|c|c|}
\hline \multirow[b]{2}{*}{ Properties } & \multicolumn{6}{|c|}{ TRIAL GROUPS } & \multicolumn{3}{|c|}{ P VALUES } \\
\hline & AY & $A Y+I Y M$ & $\mathrm{MH}$ & MH+IYM & WS & WS+IYM & feed & additive & $\begin{array}{c}\text { Feed } x \\
\text { additive }\end{array}$ \\
\hline \multicolumn{10}{|c|}{ Slaughter and carcass parameters* } \\
\hline $\mathrm{HCW}, \mathrm{kg}$ & 18.35 & 18.80 & 18.53 & 18.91 & 18.40 & 19.37 & 0.902 & 0.267 & 0.888 \\
\hline CCW, kg & 18.05 & 18.44 & 18.20 & 18.63 & 18.05 & 19.00 & 0.916 & 0.278 & 0.895 \\
\hline SW, kg & 41.55 & 41.87 & 41.32 & 41.78 & 40.47 & 42.45 & 0.935 & 0.094 & 0.400 \\
\hline $\mathrm{HCY}, \%$ & 44.03 & 44.81 & 44.91 & 45.30 & 45.42 & 45.62 & 0.687 & 0.651 & 0.973 \\
\hline $\mathrm{CCY}, \%$ & 43.31 & 43.94 & 44.10 & 44.61 & 44.56 & 44.76 & 0.711 & 0.662 & 0.986 \\
\hline \multicolumn{10}{|c|}{ Internal organ weights, g } \\
\hline Spleen & 173.50 & 170.50 & 172.84 & 176.71 & 157.50 & 161.34 & 0.261 & 0.844 & 0.923 \\
\hline Liver & 862.50 & 892.67 & 891.00 & 870.43 & 859.25 & 861.17 & 0.853 & 0.904 & 0.800 \\
\hline Lung & 670.00 & 673.00 & 637.34 & 660.86 & 648.50 & 640.00 & 0.757 & 0.846 & 0.904 \\
\hline Heart & $174.25 a$ & $195.50 b$ & $184.34 \mathrm{ab}$ & 189.14ab & $182.50 \mathrm{ab}$ & $198.84 b$ & $0.184 * *$ & 0.033 & 0.328 \\
\hline
\end{tabular}

*HCW: Hot Carcass Weight, CCW: Cold Carcass Weight, SW: Slaughter Weight, HCY: Hot Carcass Yield, CCY: Cold Carcass Yield

** Difference between the averages shown with different letters on the same line are significant statistically $(\mathrm{P}<0.05)$. 


\section{Discussion}

It is emphasized that beneficial effects of yeast, one of the feed additive agents as a stimulant for growing in the breeding industry are related with their increasing effect on the performance of ruminants (Abd-El Ghani 2004, Moharrery and Asadi 2009, Ezema 2013). In addition, adding inactivated yeast metabolite to the rations prepared with different roughage did not make any difference in the parameters of fattening performance (LW, LWG, FC, FCR) of Anatolia Merinos lambs. Apart from these researchers (Arcos-Garcia et al. 2000, Dolezal et al. 2005, Pina et al. 2006, Gomes et al. 2014) reporting the effects of yeast are related with composition of ration and the amount of yeast used in ration, some researchers (Pina et al. 2006, Gomes et al. 2014) reported that the effect is related with limiting the daily amount of roughage in the group of lambs nourished with intense feed. In this study the amount of daily roughage fed to lambs for cellulolytic activity was kept at the required level and constant during the trial. On the other hand, during the trial period (September-November) it was determined that variations of temperature and humidity during the fattening periods were significant. This indicates the parameters of fattening performance could be affected from the environmental factors such as temperature and humidity. Researchers alreadyreport (Kocaman et al. 2007, Yaganoglu 2011, Goncu et al. 2015, Niyas et al. 2015) that ambient temperature and humidity are significant environmental factors during the periods of growing and development, so in cases of ambient temperature decreases, the energy sourced by feed consumption is utilised in order to hold that temperature constant in connection with lambs' energy requirement increase and thus affecting the performance of fattening. These reports support the results of our study.

It is determined that $\mathrm{CC}$ and digestibility of $\mathrm{HCL}$ was affected by the type of roughage in ration $(P<0.05)$, additive agent increased digestibility of ADF in all groups fed by roughage $(P<0.01)$ and increased the digestibility of $C L$ in the group fed with WS $(P<0.001)$. While no relationship between the consumption of roughage with low cell wall components and the rate of digestible nutrient was observed, the consumption of roughage with high cell wall components had significant relation with the ratio of digestible nutrients and it is noted that this is the result of different levels of digestible energy provided from cell wall components (Sehu et al. 1998). It is specified that with the usage of IYM additive, more benefit can be provided from organic indigestible carbohydrate and other organic/inorganic factors, improvement on the digestive levels of feed would be observed (Grochowska et al. 2012, Rufino et al 2013). It is also specified that limited feeding, roughage: concentrate feed ratio and feed consumption, intensity of anaerobic and celluloIytic bacteria are effective factors; and in connection the digestibility of cellulose increases (Lima et al. 2012). Some researchers associated the effects of IYM with the low-quality roughage containing high $\mathrm{CL}$ in ration (Elseed and Abusamra 2007, Tang et al. 2008, Tripathi and Karim 2011 Turkmen et al. 2011, Zain et al. 2011). According to the results of this research, digestibility of other nutrients were not affected by the addition of IYM ( $P>0.05)$. It is stated that the digestibility of organic material is not affected by yeast addition and this may be caused by the digestion of yeast cell produced metabolites by rumen microorganisms (Oeztuerk 2009).

No difference was determined among the trial groups in terms of water consumption. To date, no literature exists on the water consumption of Anatolian Merinos lambs fed with IYM additives; however, it is indicated that daily water consumption of lambs vary between 3.05 - 5.7 liters (Schoeman and Visse 1995, Parker and Brown 2003). Findings regarding water consumption in this study (3.03 - $3.38 \mathrm{It} /$ day) are in line with literature.

Inactivated yeast metabolite additives decreased the rates of rumen acetic acid, propionic acid and TVFA in $\mathrm{MH}$ while increasing the rates of acetic acid and TVFA in WS $(P<0.01)$. It is stated that organic carbohydrates of acetic acid may be changed depending on the fermentation of cellulolytic bacteria (Opsi et al. 2012) and rate of propionic acid decrease significantly with cereal feeding (Lila et al. 2004, Hill et al. 2009). It is noted that concentration of total volatile fatty acid increased according to the density of bacteria in rumen and the realisation of anaerobic rumen ambiance (Arcos-Garcia et al. 2000, Alshaikh et al. 2002, Dolezal et al. 2005, Kowalik et al. 2015); however it is emphasised that it may decrease depending on the type or quality of yeast used (Angeles et al. 1998, Thrune et al. 2009, Tripathi and Karim 2011). It is stated that yeasts contribute to the maintenance of rumen $\mathrm{pH}$ due to similar reasons (Ghoneem and Mahmoud 2014). In this study rumen $\mathrm{pH}$ was also maintained. The concentration of ammonia were influenced by the type of roughage and that ruminal concentration of ammonia increased in lambs fed with $\mathrm{MH}(\mathrm{P}<0.05)$ in our study. This result was associated with the fact that $\mathrm{MH}$ contains more soluble protein than other roughage types. This is because it is expressed as an expected case that IYM addition would cause an increase in bacteria intensity in rumen and the amount of microbial nitrogen transferring to small intestine and thus ammonia nitrogen would transform into microbial protein more efficiently (Denev et al. 2007, Patra 2012). It is also indicated that the increase in ammonia and TVFA was provided for with the addition of IYM ration containing \% 49:51 roughage:strong feed (Jurkovich et al. 2014) and that the 
concentration of rumen ammonia varies due to the type of the yeast used (Arcos-Garcia et al. 2000).Slaughter weight, hot and cold carcass weights and yield; weights of spleen, liver and lung were not affected by roughage and additive matter ( $P>0.05$ ); however additive agent increased the heart weights of lambs fed with AH $(\mathrm{P}<0.05)$. These results were found similar with the results of studies stating that carcass parameters are not affected from addition of yeast (Kawas et al. 2007, Rufino et al. 2013).

\section{Conclusion}

Lamb fattening during the off-mating season, seasonal temperature and humidity variations were a significant factor on the performance; IYM additives in lamb rations had positive effects on some cell wall components digestibility and rumen fermentation; each of the as a rich roughage $\mathrm{AH}$, as a medium quality roughage $\mathrm{MH}$ or as a low quality roughage WS might be used as roughage material during lamb fattening based on intensive feed; and that further studies where higher rations of roughage are used in order to manifest the effects of IYM more clearly.

\section{Acknowledgements}

Authors thanks to Ankara University Scientific Research Projects Coordination Unit for their support. (This work was supported by Ankara University Scientific Research Projects Coordination, grant number: 15L0447004)

\section{References}

Abd-El Ghani, A. A. (2004). Influence of diet supplementation with yeast culture (Saccharomyces cerevisiae) on performance of Zaraibi goats. Small Rum. Res. 52: 223-229.

Akyıldız, A. R. (1984). Yemler bilgisi laboratuvar kılavuzu. Ankara Üniversitesi Zir. Fak. Yay. 286s. Ankara.

Alshaikh, M. A., Alsiadi, M. Y., Zahran. S. M., Mogawer, H. H., \& Aalshowime, T. A. (2002). Effect of feeding yeast culture from different sources on the performance of lactating holstein cow in Saudi Arabia. Asian-Australas. J. Anim. Sci. 15: 352-356.

Angeles, C., Mendoza, M. G. D., Cobos, P. M. A., Crosby, G. M. M., \& Castrejon, P. F. A. (1998). Comparison of commercial yeast culture (Saccharomyces cerevisiae) on ruminal fermentation and digestion in sheep fed on corn stover diet. Small Rum. Res. 31: 45-50.

Anonymous. (2014a). www.suthayvanciligi.com/urunlerimiz/ diamond- $v$

Anonymous. (2014b). www.tempe.com.tr

Anonymous. (2015). www.diamondv.com/wp-content/ uploads/ product profile_xp_Is.pdf.

Anonymous. (2016). htttps://intweb. tse.org.tr/standard. TS No: TS9610 Hayvan yemleri- metabolik (çevrilebilir) enerji tayini kimyasal metod. Kabul tarihi: 03.12.1991
Anonymous. (2006). SPSS 15.0 Command syntax reference. SPSS Inc Copyright (C) 2006 by SPSS Inc. Chicago, IL 60606-6412 www.spss.com

Arcos-Garcia, J. L., Castrejon, F. A., Mendoza, G. D., \& Perez Gavilan, E. P. (2000). Effect of two commercial yeast cultures with Saccharomyces cerevisiae on ruminal fermentation and digestion in sheep fed sugar cane tops. Livest Prod. Sci. 63: 153-157.

AOAC. (1984). Official methods of analysis (14th Ed.) association of official analytical chemists. Washington. DC. p:1112.

Chaney, A. L., \& Marbaeh, E. P. (1962). Modified reagents for determination of urea and ammonia. Clin. Chem. 8: 130-132.

Dağsöz, A. K., \& Bayraktar, K. G. (1999). Türkiye'de derece-gün sayıları ve enerji politikamız. yapıda yalıtım konferansı bildiriler kitabı. İstanbul.

Denev, S. A., Peeva, T., Radulova, P., Stancheva, N., Staykova, G., Beev, G., Todorova, P., Tchobanova, S. (2007). Yeast cultures in ruminant nutrition. Bulg. J. Agric. Sci. 13: 357-374.

Dolezal, P., Dolezal, J., \& Trinacty, J. (2005). The effect of Saccharomyces cerevisiae on ruminal fermentation in dairy cows. Czech J. Anim. Sci.50: 503-510.

Düzgüneş, O., Kesici, T., \& Gürbüz, F. (1987). İstatistik metodları-I. A.Ü. Zir. Fak. Yay. 861. Ders Kitabı: 299. 218 s. A.Ü. Basımevi. Ankara.

Duncan, D. B. (1955). Multiple range and multiple f test. Biometrics 11: 1-42.

Elseed, F., \& Abusamra, M. A. (2007). Effects of supplemental yeast (Saccharomyces cerevisiae) culture on NDF digestibility and rumen fermentation of forage sorghum hay in Nubian goat's kids. Res. J. Agric. \& Biol. Sci. 3(3):133-137.

Ezema, C. (2013). Probiotics in animal production: A review. J. Vet. Med. Anim. Health 5(11): 308-316.

Ghoneem, W. M. A., \& Mahmoud, A. E. M. (2014). Effect of inactivated and dried yeast on productive performance of Barki lambs. Asian J. Anim. Vet. Adv. (C2014 Academic J. Inc.

Gomes, L. C., Alcalde, C. R., Lima, L. R., Lima, L. S., Souza, R., \& Possamai, A. P. S. (2014). Nutritive value of diets containing inactive dry yeast for lactating Saanen goats. R. Bras. Zootec. 43(1):36-43.

Göncü, S., Önder, D., Koluman, N., \& Mevliyaoğulları, E. (2015). Sıcak ve nemli koşullara uygun hayvan barınak özellikleri. Tüsedad 5(30): 42-47.

Grochowska, S., Nowak, W., Mikuła, R., \& Kasprowicz-Potocka, M. (2012). The Effect of Saccharomyces cerevisiae on ruminal fermentation in sheep fed high- or low-NDF rations. J. Anim. Feed Sci. 21: 276-284.

Haddad, S. G., \& Goussous, S. N. (2005). Effect of yeast culture supplementation on nutrient intake, digestibility and growth performance of Awassi lambs. Anim. Feed. Sci. Technol. 118: 343-348.

Hill, S. R., Hopkins, B. A., \& Davidson, S. (2009). The addition of cottonseed hulls to the starter and supplementation of live yeast or mannanoligosaccharide in the milk for young calves. J. Dairy Sci. 92: 790-798.

Inge, N. A., Bogaert, V., \& Maeseneire, L. D. (2009). Extracellular polysaccharides produced by yeast and yeast-like fungi. yeast biotechnology: Diversity App. 651-671. 
Jurkovich, V., Brydl, E., Kutasi, J., Harnos, A., Kovacs, P., Könyves L., Muravölgyi, \& Febel, H. (2014). The effects of Saccharomyces cerevisiae strains on the rumen fermentation in sheep fed with diets of different forage to concentrate ratios. J. Appl. Anim. Res. 42 (4): 481-486.

Karademir, G., \& Karademir, B. (2003). Yem katkı maddesi olarak kullanılan biyoteknolojik ürünler. Lalahan Hay. Araşt. Enst. Derg. 43: 61-74.

Kawas, J. R., García-Castillo, F., Garza-Cazares, H., FimbresDurazo, Olivares-Sáenz, E., Hernández-Vidal, G., \& Lu, C. D. (2007). Effects of sodium bicarbonate and yeast on productive performance and carcass characteristics of light-weight lambs fed finishing diets. Small Rum. Res. 67: 157-163.

Kocaman, İ., Konukçu, F., \& İstanbulluoğlu, A. (2007). Hayvan barınaklarında isı ve nem dengesi. KSÜ Fen \& Müh. Derg. 10(1): 137-140.

Kocaoğlu, G. B., \& Kara, K. (2010). Ruminant beslemede alternatif yem katkı maddelerinin kullanımı: 2. organik asit, yağ asiti, adsorban. Erciyes Üniv. Vet. Fak. Derg. 7: 43-52.

Kowalık, B., Skomial, J., Miltko, R., \& Majewska, M. (2015). The effect of live Saccharomyces cerevisiae yeast in the diet of rams on the digestibility of nutrients, nitrogen and mineral retention and blood serum biochemical parameters. Turk J. Vet. Anim. Sci. (2016) 40: () TÜBITAK.

Lila, Z. A., Mohammed, N., Yasui, T., Kurokawa, Y., Kanda, S., \& Itabashi, H. (2004). Effects of twin strain of Saccharomyces cerevisiae live cells on mixed ruminal microorganism fermentation in vitro. J. Anim. Sci. 82: 1847-1854.

Lima, L. S., Alcalde, C. R., Gomes, L. C., Souza, R., Rigolon, L. P., \& Nakamura, C. V. (2012). Effect of inactive dry yeast from sugar cane as protein source on rumen fermentation in saanen goats. Arg. Bras. Med. Vet. Zootec. 64(1): 145-154.

Moharrery, A., \& Asadi, E. (2009). Effects of supplementing malate and yeast culture (Saccharomyces cerevisiae) on the rumen enzyme profile and growth performance of lambs. J. Anim. Feed Sci. 18: 283-295.

Niyas, P. A., Chaidanya, K., Shaji, S., Sejian, V., Bhatta, R., Bagath, M., Rao, G., Kurien, E., \& Girish, V. (2015). Adaptation of livestock to environmental challenges. J. Vet. Sci. Med. Diagn. 4: 3.

NRC. (2007). Nutrient requirements of small ruminants. Animal Nutrition Series. National Research Council. Washington. D.C.

Oeztuerk, H. (2009). Effects of live and autoclaved yeast cultures on ruminal fermentation in vitro. J. Anim. Feed. Sci. 18: 142150.

Opsi, F., Fortina, R., Tassone, S., Bodas, R., \& Lopez, S. (2012). Effects of inactivated and live cells of Saccharomyces cerevisiae on in vitro ruminal fermentation of diets with different forage: concentrate ratio. J. Agr. Sci. 150: 271-283.

Parker, D. B., \& Brown, M. S. (2003). Water consumption for livestock and poultry production. Encyclopaedia of Water Sci. 1-5.

Patra, A. K. (2012). The use of live yeast products as microbial feed additives in ruminant nutrition. Asian J. Anim. Vet. Adv. 7(5): 366-375.

Pina, D. S., Valadares Filho, S. C., Valadares, R. F. D., Campos, J. M. S., Detmann, E., Marcondes, M. I., Oliveira, A. S., \& Teixeira, R. M. A. (2006). Consumo e digestibilidade aparente total dos nutrientes. produção e composição do leite de vacas alimentadas com dietas contendo diferentes fontes de proteína. R. Bras. Zootec. 35:1543-1551.
Playne, M. J. (1985). Determination on ethanol volatile fatty acids, lactic and succinic acids in fermentation liquids by gas chromatography. J. Sci. Food Agr. 36(6): 638-644.

Rentfrow, G. (2010). How much meat to expect from a carcass. Anim. Food Sci. University of Kentucky College of Agriculture, Lexington, KY, 40546 ASC-179.

Rufino, L. D. A., Pereira, O. G., Ribeiro, K. G., \& Valadares Filho, S. C. (2013). Effect of substitution of soybean meal for inactive dry yeast on diet digestibility, lamb's growth and meat quality. Small Rum. Res. 111: 56-62.

Schoeman, S. J., \& Visse, J. A. (1995). Water intake and consumption in sheep differing in growth potential and adaptability. S. Afr. J. Anim. Sci. 25(2): 75-79.

Şehu, A., Yalçın, S., \& Önol, A. G. (1998). Kaba yemlerin bazı özelliklerinden yararlanarak kuzularda kuru madde tüketimi ve canlı ağırlık artışının belirlenmesi. Turk J. Vet. Anim. Sci. 22: 475-483СTÜBITAK.

Tang, S. X., Tayo, G. O., Tan, Z. L., Sun, Z. H., Shen, L. X., Zhou, C. S., Xiao, W. J., Ren, G. P., Han, X. F., \& Shen, S. B. (2008). Effects of yeast culture and fibrolytic enzyme supplementation on in vitro fermentation characteristics of low-quality cereal straws. J. Anim. Sci. 86: 1164-1172.

Thrune, M., Bach, A., Ruiz-Moreno, M., Stern M. D., Linn, \& J. G. (2009). Effects of Saccharomyces cerevisiae on ruminal $\mathrm{pH}$ and microbial fermentation in dairy cows: yeast supplementation on rumen fermentation. Livestock Sci. 124(1): 261-265.

Tripathi, M. K., \& Karim, S. A. (2011). Effect of yeast cultures supplementation on live weight change, rumen fermentation, ciliate protozoa population, microbial hydrolytic enzymes status and slaughtering performance of growing lamb. Livestock Sci. 135: 17-25.

Türkmen, İ. İ., Biricik, H., Deniz, G., Gezen, Ş. Ş., Tuncer, Ş. D., Çolpan, İ., Küçükersan, M. K., Küçükersan, S., Yalçın, S., Şehu, A., Saçaklı, P., Ergün, A., \& Yıldız, G. (2011). Temel yem bilgisi ve hayvan besleme. Anadolu Ünv. Yay. 70-88, 1. Baskı. Eskişehir Turkey.

Van Soest, P. J. (1994). Fiber and physicochemical properties of feeds in: nutritional ecology of the ruminant. Cornell University press. pp. 140-155.

Vyas, D., Uwizeye, A., Mohammed, R., Yang, W. Z., Walker, N. D., \& Beauchemin, K. A. (2014). The effects of active dried and killed dried yeast on subacute ruminal acidosis, ruminal fermentation and nutrient digestibility in beef heifers. J. Anim. Sci. 92: 724-732.

Yağanoğlu, A. V. (2011). Hayvan barınaklarında çevre koşullarının düzenlenmesi. Atatürk Üniv. Zir. Fak. Derg. 17(1): 121-129.

Zain, M., Jamarun, N., Arnim, A., Ningrat, R.W.S., \& Herawati, R. (2011). Effect of yeast (Saccharomyce cerevisiae) on fermentability, microbial population and digestibility of low quality roughage in vitro. Archiva Zootech. 14(4): 51-58.

Zdunczyk, Z., Gruzauskas, R., Juskiewicz, J., Dauksiene, A., Raceviciute-Stupeliene, A., \& Jarule, V. (2013). Effect of dietary probiotic, prebiotic mannanoligosaccharides and their combination on caecal parameters in hens. Vet. Med. Zoot. 63 (85). 